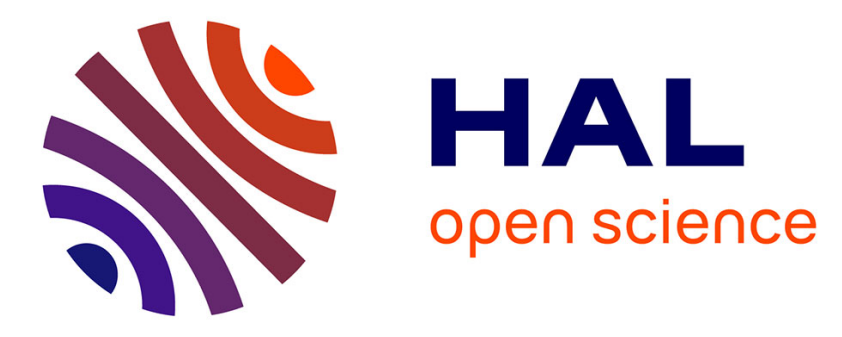

\title{
Spartina versicolor Fabre: Another case of Spartina trans-Atlantic introduction?
}

\author{
Alex Baumel, Mathieu Rousseau-Gueutin, C. Sapienza-Bianchi, Agnès Gareil, \\ N. Duong, Hélène Rousseau, Olivier Coriton, Rachid Amirouche, S. \\ Sciandrello, B. Duarte, et al.
}

\section{To cite this version:}

Alex Baumel, Mathieu Rousseau-Gueutin, C. Sapienza-Bianchi, Agnès Gareil, N. Duong, et al.. Spartina versicolor Fabre: Another case of Spartina trans-Atlantic introduction?. Biological Invasions, 2016, 18 (8), pp.2123-2135. 10.1007/s10530-016-1128-z . hal-01355664

\section{HAL Id: hal-01355664 https://hal.science/hal-01355664}

Submitted on 25 Apr 2018

HAL is a multi-disciplinary open access archive for the deposit and dissemination of scientific research documents, whether they are published or not. The documents may come from teaching and research institutions in France or abroad, or from public or private research centers.
L'archive ouverte pluridisciplinaire HAL, est destinée au dépôt et à la diffusion de documents scientifiques de niveau recherche, publiés ou non, émanant des établissements d'enseignement et de recherche français ou étrangers, des laboratoires publics ou privés. 


\title{
Spartina versicolor Fabre: Another case of Spartina trans-Atlantic introduction?
}

\author{
A. Baumel - M. Rousseau-Gueutin - C. Sapienza-Bianchi • A. Gareil • N. Duong • \\ H. Rousseau $\cdot$ O. Coriton $\cdot$ R. Amirouche $\cdot$ S. Sciandrello $\cdot$ B. Duarte $\cdot$ I. Caçador $\cdot$ \\ J. M. Castillo $\cdot$ M. Ainouche
}

\begin{abstract}
Intercontinental introductions are widespread in the genus Spartina, with important ecological and evolutionary consequences. The native or introduced status of Spartina species is then critical with regard to biodiversity assessment, especially for vulnerable Mediterranean coastline ecosystems. Spartina versicolor was first recorded in southern France in 1849, then successively in various places on the European and North-African Mediterranean and Atlantic coasts. This species is considered to be either a European native or an invasive species introduced from North America which has a high morphological
\end{abstract}

A. Baumel · N. Duong

Aix Marseille Université, Institut Méditerranéen de Biodiversité et d'Ecologie (IMBE, UMR CNRS, IRD, Avignon Université), Technopôle de l'Environnement Arbois-Méditerranée, BP 80,

13545 Aix-en-Provence Cedex 04, France

M. Rousseau-Gueutin · C. Sapienza-Bianchi ·

A. Gareil · H. Rousseau · M. Ainouche $(\varangle)$

UMR CNRS 6553 Ecobio, OSUR (Observatoire des

Sciences de l'Univers de Rennes), Université de Rennes

1/Université Européenne de Bretagne, 35042 Rennes,

France

e-mail: malika.ainouche@univ-rennes1.fr similarity to the Atlantic American species Spartina patens. We performed extensive sampling of $S$. versicolor in Europe and North Africa (from natural populations and herbarium collections) and compared these samples to other European and American Spartina species (including S. patens). Chromosome counts were reported for the first time and revealed that $S$. versicolor is tetraploid $(2 n=4 x=40)$. Phylogenetic analyses based on chloroplast and nuclear ribosomal DNA sequences did not reveal any molecular variation within $S$. versicolor. In this species, a single haplotype, that is identical to one haplotype of $S$. patens, was found in the four chloroplast and the nuclear ribosomal ITS regions investigated. In addition, simple sequence repeat markers were used and revealed a low level of genetic diversity within $S$. versicolor, suggesting that the introduction of $S$.

M. Rousseau-Gueutin

INRA, UMR 1349, Institut de Génétique, Environnement et Protection des Plantes, 35653 Le Rheu Cedex, France

O. Coriton

Plate-Forme de Cytogénétique Moléculaire, INRA, UMR 1349, Institut de Génétique, Environnement et Protection des Plantes, 35653 Le Rheu Cedex, France

R. Amirouche

Université des Sciences et de la Technologie Houari Boumediene, Laboratoire de Biologie et Physiologie des Organismes, BP 32 El-Alia, 16111 Bab-Ezzouar, Alger, Algeria 
versicolor occurred from a narrow genetic pool of $S$. patens from North America.

Keywords Cordgrass - Genetic diversity $\cdot$ Species status · Mediterranean · Microsatellites · Phylogeny

\section{Introduction}

Wetland habitats are among the most threatened in the Mediterranean as a consequence of intense urbanization, anthropogenic disturbance and increased number of invasive taxa (Médail and Verlaque 1997). In France, Mediterranean wetlands are among the habitats that are the most colonized by invasive species (Verlaque et al. 2002). Because surveys of biodiversity are generally poorly coordinated in the Mediterranean biodiversity hotspot (Marignani et al. 2014), inference of the native or introduced plant species status is not trivial. This status is an essential parameter for biodiversity management and conservation biology. It also represents critical information with regard to population and species evolutionary history. Establishing native status for a species in a given region is not an easy task and requires a combination of different approaches to elucidate the origin, mode of formation and biogeography of the considered taxon. The increased opportunities for long-distance humanmediated species dispersal make these researches even more complex (Kowarik 2003). In this context, molecular markers and evolutionary genetics provide important insight to trace back population, species origin and migration history (Mansion et al. 2008; Hardion et al. 2014).

S. Sciandrello

Department of Biological, Geological and Environmental Sciences, University of Catania, via Alongo 18, 95125 Catania, Italy

B. Duarte · I. Caçador

MARE - Marine and Environmental Sciences Centre, Faculty of Sciences of the University of Lisbon, Campo Grande, 1749-016 Lisbon, Portugal

\section{J. M. Castillo}

Departamento de Biología Vegetal y Ecología, Facultad de Biologia, Universidad de Sevilla, Apartado 1095, 41080 Seville, Spain
In Spartina (cordgrasses), recurrent intercontinental introduction events and biological invasions are particularly common and well-documented (Daehler and Strong 1996a, b; San Léon et al. 1999; Baumel et al. 2001; Sanchéz-Gullon 2001; Ayres et al. 2004; An et al. 2007; Ainouche et al. 2009; Campos et al. 2004; Lonard et al. 2010; Saarela 2012; Strong and Ayres 2013). This grass genus (Poaceae, Chloridoideae) represents a wellsupported monophyletic lineage (Baumel et al. 2002; Fortune et al. 2007) closely related to some members of the paraphyletic Sporobolus genus and Calamovilfa (Peterson et al. 2014). It is composed of about 15 perennial species that have diversified mostly in the New World (Mobberley 1956). Introduction of species outside their native range over the past 150 years has accelerated diversification by facilitating hybridization with native species, introgression or speciation, resulting in several superimposed divergent genomes that coexist in the species currently found in the wild (Ainouche et al. 2012). The basic (haploid) chromosome number in Spartina is considered to be $x=10$ (Marchant 1968), and all species recorded to date are polyploid, ranging from tetraploids to dodecaploids. Molecular phylogenies from nuclear and chloroplast DNA sequences have indicated that genus Spartina has evolved through two main lineages including tetraploid and hexaploid species respectively (Baumel et al. 2002). The tetraploid lineage is composed of species native to the New World, colonising coastal or inland salt marshes from either Northern (Spartina patens, Spartina bakeri, Spartina gracilis, Spartina cynusoroides, Spartina pectinata) or Southern (Spartina ciliata, Spartina arundinacea) hemispheres. The tetraploid $S$. argentinensis (syn. S. spartinae), which has a disjunct distribution in North-Central America and in SouthAmerica, is sister to the hexaploid lineage. This later clade is composed of Spartina maritima, Spartina alterniflora, and Spartina foliosa, all colonizing low marsh zones. Spartina maritima, native to the Western Europe and African Atlantic coasts, is one of the few Old World native species with recent taxa of hybrid origin and the controversial S. versicolor (see below). Accidental or deliberate introductions lead to various hybridization events within or between the tetraploid and hexaploid lineages (reviewed in Ainouche et al. 2012; Strong and Ayres 2013).

In Europe, introductions of the hexaploid $S$. alterniflora, native to the Atlantic American coasts and its subsequent hybridization with hexaploid $S$. 
maritima led to the formation of two sterile F1 hybrids in Southern England (S. $x$ townsendii) and in Southwest France ( $S$. $x$ neyrautii). Genome duplication in the British hybrid resulted in the vigorous and fertile allododecaploid S. anglica (Hubbard 1968; Guénégou et al. 1988; Gray et al. 1990; Gray et al. 1991). This species rapidly expanded in range and spread naturally to western European saltmarshes. It is now introduced in various continents, leading to various attempts to control or eradicate the species (e.g. Hacker et al. 2001; Cottet et al. 2007). Introduced S. alterniflora is progressing along the western Atlantic coasts of France and Spain (Baumel et al. 2003; Campos et al. 2004). Another introduced Spartina species in Europe is the native South-American heptaploid species $S$. densiflora (Fortune et al. 2008) that is invading Mediterranean saltmarshes of the Iberian peninsula (Bortolus 2006; Castillo et al. 2008), where it hybridized with the hexaploid S. maritima (Castillo et al. 2010).

In the western Mediterranean, damp depressions in dune habitats are colonized by Spartina versicolor Fabre (Fig. 1) that grows also in brackish marshes in the Atlantic Coast of the Southwest Iberian Peninsula. This species, also named Spartina juncea or Spartina durieui (Chevalier 1923; Saint-Yves 1932), had a controversial taxonomic status. It was initially recorded almost simultaneously in several Mediterranean places: first in Southern France near Agde (Fabre 1849), then in Italy (Parlatore 1848-1850), Algeria (Cosson and Maisonneuve 1867), and Portugal (Daveau 1897). In 1901, Neyraut detected this taxon on the Southwest French Atlantic coast, near
Arcachon (Coste 1906). Since then, S. versicolor has established all along the western Mediteranean coasts: in Corsica (Jeanmonod and Burdet 1989) as well as on the Atlantic and Mediterranean coasts of the Iberian Peninsula (Sanchéz-Gullón 2001). S. versicolor was considered as either a native Mediterranean plant (e.g. Sanchéz-Gullón 2001; Giuliano and Stanisci 2010; Tison et al. 2014a, b), or an invasive species introduced from America (Sanz Elorza et al. 2004; Tison and de Foucault 2014). Based on morphological similarities, Mobberley (1956) considered S. versicolor as synonymous to $S$. patens, assuming that the Mediterranean populations were introduced from the Atlantic North American coast where S. patens is abundant in high marsh and dunes. Recent studies on salt marshes along the Spanish Atlantic coast have underlined the presence of $S$. patens in Europe (San Leon 1999; Page et al. 2010) and renewed interest in the status of $S$. versicolor. Prieto et al. (2011) examined three $S$. versicolor individuals from northern Spain (Asturias) using Internal transcribed Spacer (ITS) sequences of nuclear ribosomal DNA genes, and compared these sequences to those initially published in genus Spartina by Baumel et al. (2002) and Ferris et al. (unpublished). These individuals exhibited similar ITS sequence to S. patens, which led these authors to suggest that $S$. versicolor should be considered as $S$. patens. But it cannot be excluded that a native Mediterranean Spartina species exists besides the introduction of $S$. patens in Spain. Cases of cryptic invasion have already been documented in the recent history of Spartina (e.g. Bortolus et al. 2015) and can be difficult to detect (Valtuena et al. 2011).
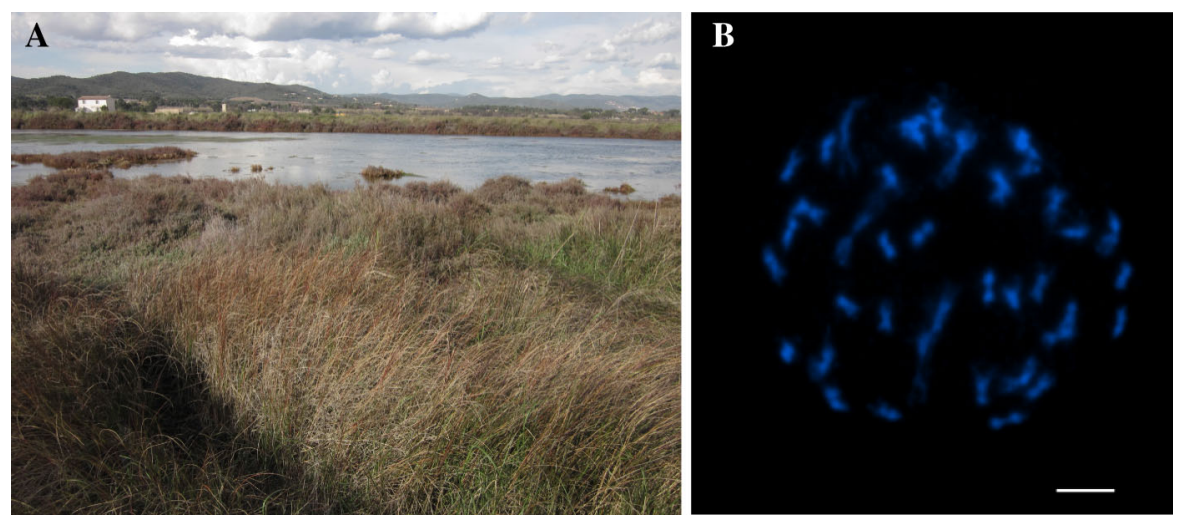

Fig. 1 Spartina versicolor a vigorous population from Vieux Salins (Hyères, France) b mitotic chromosomes counterstained with DAPI $(2 \mathrm{n}=40)$, bar represents $5 \mu \mathrm{m}$ 
In this study, we aim at answering the following questions: Is $S$. versicolor Fabre from Europe conspecific with $S$. patens from North America and if so is European $S$. patens another case of trans-Atlantic introduction into Europe? As highlighted above, worldwide invasions of Spartina are common phenomena and the Mediterranean coast may be one of the various places where American Spartina have settled after dispersal by ships during the 18th or 19th centuries. Gaining insight into the native or introduced status of S. versicolor, to its relationship with other Spartina species will be of critical importance in order to better understand the biogeography and diversification of Spartina species, as well as to determine the conservation priority level and management policy of S. versicolor in the Old World. To answer these questions, populations of S. versicolor sampled from various Mediterranean and Atlantic sites in Europe and North-Africa (including reference types from herbaria) are analyzed using cytogenetic and molecular (microsatellite, nuclear and chloroplast DNA sequences) data, and compared to North-American Spartina species.

\section{Materials and methods}

Plant material

Fifty-seven individuals of $S$. versicolor were sampled from numerous Mediterranean sites $(n=47)$ and from herbarium collections $(\mathrm{n}=10)$ (Table $\mathrm{S} 1)$. The analyzed samples include specimens from various populations in France (including Corsica), Italy, Portugal, Spain and Algeria as well as the first $S$. versicolor plants from Agde (France) discovered by Fabre (1849). Eight Spartina patens samples were obtained from the Atlantic North American coast (Table S1). Representatives from eight other Spartina species (S. argentinensis, S. alterniflora, S. arundinacea, S. bakeri, S. densiflora, S. foliosa, S. maritima and S. pectinata) and from Sporobolus cryptandrus were additionally introduced in phylogenetic analyses.

\section{Chromosome counts}

The chromosome number of $S$. versicolor was determined on mitotic chromosomes obtained from two plants collected in France (Vieux Salins and Saint-
Louis du Rhone). Mitotic chromosomes were observed on metaphasic cells isolated from root tips. The roots tips of $0.5-1.5 \mathrm{~cm}$ length were treated with $0.04 \% 8$-hydroxiquinoline for $2 \mathrm{~h}$ at $4{ }^{\circ} \mathrm{C}$ in the dark followed by $2 \mathrm{~h}$ at room temperature to accumulate metaphases, then fixed in ethanol-acetic acid $(3: 1, v / v)$ for $12 \mathrm{~h}$ at $4{ }^{\circ} \mathrm{C}$ and stored in ethanol $70 \%$ at $-20{ }^{\circ} \mathrm{C}$. After washing in $0.01 \mathrm{M}$ enzyme buffer (citric acidsodium citrate $\mathrm{pH} 4.5$ ) for $15 \mathrm{~min}$, the roots were digested in a solution of $5 \%$ Onozuka R-10 cellulase (Sigma) and $1 \%$ Y23 pectolyase (Sigma) at $37{ }^{\circ} \mathrm{C}$ for $30 \mathrm{~min}$. The root tips were then washed with distilled water for $30 \mathrm{~min}$. Root tips transferred on a slide were squashed in a drop of 3:1 ethanol-acetic acid fixation solution. After air-drying, slides were stained with 4,6diamidino-2-phenylindole (DAPI). Fluorescence images were captured using a CoolSnap HQ camera (Photometrics, Tucson, Ariz) on an Axioplan 2 microscope (Zeiss, Oberkochen, Germany) and analysed using MetaVue ${ }^{\mathrm{TM}}$ (Universal Imaging Corporation, Downington, PA).

DNA isolation, PCR amplification and DNA sequencing

Genomic DNA was isolated from $100 \mathrm{mg}$ of fresh (or $30 \mathrm{mg}$ of herbarium) leaves from each individual using the NucleoSpin ${ }^{\circledR}$ Plant II Kit (MachereyNagel), following instructions provided by the manufacturer. DNA concentrations were estimated using the Nanodrop Spectrophotometer ND 1000 (Thermo Fischer Scientific).

Four chloroplast and ten nuclear regions were amplified. Chloroplast sequences were chosen among the most variable intergenic regions identified in Poaceae (Rousseau-Gueutin et al. 2015) or within Spartina (Blum et al. 2007; Kim et al. 2013): it included the $n d h \mathrm{C}-t r n \mathrm{~V}$, pet $\mathrm{A}-p s b \mathrm{~J}$ (primers designed from Rousseau-Gueutin et al. 2015), and the $\operatorname{trn} \mathrm{L}-\operatorname{trn} \mathrm{F}$ and trnT-trnL intergenic regions (Taberlet et al. 1991). Nuclear regions included Internal transcribed Spacers (ITS) of nuclear ribosomal genes (rDNA) (White et al. 1990) and nine microsatellite markers (SSR 6, 40, 44, $72,109,122,161,172,188)$ identified from $S$. maritima Bacterial Artificial Chromosome end sequences (Ferreira de Carvalho et al. 2013). The primer sequences used in this study are indicated in Table S2. 
Amplifications of chloroplast and ITS regions were carried out using the high fidelity KOD polymerase (Toyobo, Novagen) in a total volume of $50 \mu \mathrm{l}$. The reaction mix included $1 \mathrm{X}$ of $\mathrm{KOD}$ buffer, $1.5 \mathrm{mM}$ MgSO4, $0.2 \mathrm{mM}$ dNTP, $0.3 \mu \mathrm{M}$ of each primer, 0.02 $\mathrm{U}$ of KOD polymerase, and $20 \mathrm{ng}$ template DNA. Cycling conditions were $94{ }^{\circ} \mathrm{C}$ for $2 \mathrm{~min}$, followed by 32 rounds of $94{ }^{\circ} \mathrm{C}$ for $20 \mathrm{~s}, 59.5{ }^{\circ} \mathrm{C}$ for $10 \mathrm{~s}$ and an extension at $70{ }^{\circ} \mathrm{C}$ for $15 \mathrm{~s}$. Chloroplast and nuclear (ITS) PCR products were purified using the PCR Clean-up Gel extraction kit (Macherey-Nagel) and the purified products were sent to Macrogen Europe (Amsterdam, Netherlands) for direct sequencing. Long PCR products (from the $\operatorname{trn} \mathrm{T}-\operatorname{trn} \mathrm{L}$, $\operatorname{trn} \mathrm{L}-\operatorname{trn} \mathrm{F}$ and $n d h \mathrm{C}-t r n \mathrm{~V}$ regions) were sequenced from both sides. Sequences were cleaned and verified visually on the chromatograms (no double peaks observed).

Simple Sequence Repeat (SSR) detection was performed for 60 samples (52 Old Word S. versicolor and 8 New World $S$. patens) using 9 microsatellite loci. Amplifications of all microsatellites were performed in $20 \mu \mathrm{L}$ that contained $10 \mathrm{ng}$ DNA, $4 \mu \mathrm{L}$ of $5 \mathrm{X}$ buffer, $4 \mathrm{mM} \mathrm{MgCl} 2,0.2 \mathrm{mM}$ dNTPs, $0.4 \mu \mathrm{M}$ of each primer, and 0.4 units of $T a q$ polymerase (QBiogen) in a PTC-200 Gradient Thermal Cycler (MJ Research), following touchdown PCR protocols (Migliore et al. 2013). The $5^{\prime}$ ends of the forward primers were labelled with PET or NED. The fluorescently labelled PCR products were diluted (1/40) and were separated by capillary electrophoresis, with a 500 bp size standard (LIZ500), using an ABI Prism ${ }^{\circledR}$ 3730xl (Applied Biosystems) automatic sequencer. Alleles were sized using PEAK SCANNER 1.0 software (Applied Biosystems). Genotyping (PCR and electrophoresis) was repeated for 8 samples to verify the reproducibility of the peak patterns.

\section{Phylogenetic analyses}

The data matrices generated for individual or concatenated chloroplast regions as well as the nuclear ITS matrix were obtained after aligning all sequences using Geneious (Drummond et al. 2010) and adjusting them manually. These matrices were first subjected to phylogenetic analyses using maximum parsimony. Sequence data were analyzed using PAUP* v4.0b10 (Swofford 2001) with heuristic search and the default search options. The phylogenetic analyses were performed using sequences from Sporobolus cryptandrus, a closely related species to Spartina (Peterson et al. 2014) as outgroup. Bootstrap analyses were performed with 1000 replicates (Felsenstein 1985). In addition, these data matrices were subjected to Maximum Likelihood phylogenetic analyses. The best-fitted model of sequence evolution for each region (individual or concatenated) was determined by using JModeltest (Posada 2008) implemented in MEGA 5.0 (Tamura et al. 2011). Maximum likelihood analyses were then performed for each matrix using PhyML (Guindon and Gascuel 2003), with 1000 replicates of bootstrap.

\section{Microsatellite analyses}

Out of the nine SSR loci, six were considered to be reliable and were subsequently analyzed. After comparisons of replicates, all dubious peaks were removed. Since most genotypes have at least three alleles in this polyploid species (see below), SSR markers were analyzed as binary data and the matrix of allele size was converted into presence/absence data matrix. Genalex 6.51 software (Peakall and Smouse 2006) was used to search for matching genotypes, bearing evidence for identical clones. The search for matching genotype was repeated accounting for one, two or three allelic errors. Allelic accumulation curves were performed (specaccum function, vegan $\mathrm{R}$ package, Oksanen et al. 2013) to match allelic richness of $S$. versicolor and S. patens.

Structure of genetic diversity was analyzed using multivariate analyses of ade 4 and adegenet packages of R (Dray and Dufour 2007; Jombart 2008). Principal coordinate analysis (PcoA, dudi.pco function, ade4 R package) was based on Jaccard distances (Jaccard 1901) computed on SSR presence/absence (dist.binary function, ade $4 \mathrm{R}$ package). For matching samples having identical genotypes (clones), only one genotype was kept in analyses based on individual genotypes and these were identified as "clones" on the PcoA plot. A discriminant analysis was conducted on the correlation of allele presence/absence to distinguish genetic groups according to the clustering procedure designed by Jombart et al. (2010) (DAPC analysis, adegenet $\mathrm{R}$ package). Finally, allele frequencies within these groups were used to compute Nei distances (Nei 1972) and to build a Neighbor Joining network to explore relationships between DAPC 
genetic groups (nj function, ape $\mathrm{R}$ package, Paradis et al. 2004).

\section{Results}

Chromosome counts revealed that in both analyzed populations, S. versicolor individuals have $2 n=40$ chromosomes (Fig. 1b), indicating that this taxon is a tetraploid species.

No sequence heterogeneity was observed in either chloroplast or nuclear (ITS) sequences. Intra-genomic polymorphism might be expected in polyploid nuclear genomes, but the ITS regions (belonging to the rDNA gene family) seem to have undergone concerted evolution as previously found in other Spartina species (Baumel et al. 2002; Boutte et al. 2015). Maximum Parsimony (MP) analyses were performed using the $n d h \mathrm{C}-t r n \mathrm{~V}(601 \mathrm{bp})$, petA-psbJ (470 bp),

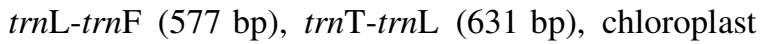
concatenated (2278 bp) or nuclear ribosomal ITS (457 bp) matrices. These analyses resulted in 23, 34, 20, 23, 3 and 19 equal most parsimonious trees. In these analyses, $S$. versicolor, S. patens and S. bakeri always belonged to the same clade (Fig. 2). For the most resolved tree corresponding to the ITS regions, these three species belong to a well-supported clade (99\%) and are as positioned as a sister clade to $S$. arundincacea and S. densiflora (100\% bootstrap support). The sequences obtained from all $S$. versicolor (including the sequences obtained by Prieto et al. 2011) and S. patens samples were identical, apart from a single substitution observed in one accession of $S$. patens (Cheesequake state Park, Florida) for the $n d h \mathrm{C}$ trn $\mathrm{V}$ region. $S$. versicolor and $S$. patens are closely related to $S$. bakeri, presenting only two substitutions (one for the $n d h \mathrm{C}$-trn $\mathrm{V}$ and one for the ITS regions). Since similar tree topologies were obtained using Maximum Likelihood, only the MP trees are presented here.

Thirty-seven alleles were recorded over the six SSR loci. All SSR genotypes were heterozygous with mostly 3 or 4 alleles per locus. Within S. versicolor, search for matching genotypes revealed 35 genotypes among 52 samples, 31 being unique and 4 being repeated from 4 to 11 times. These identical genotypes are referred as "clones". Accounting for one, two or three allele errors we found 41, 44 and 50 matching genotypes in $S$. versicolor, whereas no matching
Fig. 2 Molecular phylogeny of Spartina based on chloroplast (a $n d h \mathrm{C}-t r n \mathrm{~V}: 601 \mathrm{bp}$; b petA-psbJ: 470 bp, c trnL-trnF: 577 bp, d $\operatorname{trnT}$ T-trnL: $631 \mathrm{bp}$, e concatenated sequences: $2278 \mathrm{bp}$ ) or f nuclear ribosomal ITS sequences (457 bp) using the maximum parsimony method. For each phylogeny, one of the equally parsimonious trees that is topologically identical to the $50 \%$ majority-rule consensus tree (petA-psbJ: 34 equally parsimonious trees; concatenated chloroplast sequences: three equally parsimonious trees; ITS: 19 equally parsimonious trees) or the $50 \%$ majority-rule consensus tree (ndhC-trn V: 23 parsimonious trees; trnL-trnF: 20 parsimonious trees) is presented. The bootstrap percentages (1000 replicates) are shown in bold above the branches and the number of changes is indicated below. The tree is rooted using either Sporobolus cryptandrus or Sorghum bicolor

genotypes were found among the 8 samples of $S$. patens even accounting for 3 allele errors. Accumulation curve (Fig. 3) accounting for the unequal sampling between $S$. versicolor $(\mathrm{n}=52)$ and $\mathrm{S}$. patens $(\mathrm{n}=8)$ revealed higher allelic diversity in $S$. patens than in S. versicolor: i.e. for 6 samples 32 alleles were encountered in $S$. patens against 26 in $S$. versicolor (Fig. 3).

The PcoA analysis based on Jaccard distances computed between individual genotypes (Fig. 4) revealed that the main structure is due to differentiation between 6 out of $8 S$. patens genotypes. The other $2 S$. patens samples are more similar to $S$. versicolor genotypes. Herbarium specimens are scattered among $S$. versicolor genotypes, except one (collected in Carnon, France, in 1880 by Jouve) that is grouped with S. patens (H6, Fig. 4). The herbarium specimen collected by Fabre in (1849) in Agde has one of the genotypes recorded on many individuals ("matching genotypes" see Materials and methods) and identified as clone "b" (Fig. 4). This clone is found in France, Basque area, Italy and Sicily. According to the DAPC analysis (Fig. 4) and NJ network (Fig. 5), the SSR genotypes were optimally clustered in six groups. The genetic cluster number 4 (represented in green, Figs. 5, 6) was composed of European samples from France (natural populations and most herbarium samples), Italy, Corsica, and North Spain. The individuals from the southern Iberic Peninsula (south of Spain and Portugal) and Algeria are grouped in two (1 and 6) closely related clusters. Three genetic clusters could be distinguished in the American samples of $S$. patens: (1) Mexico-Florida-Delaware (2) New Jersey and (3) NewJersey Hampshire. The herbarium sample from France sampled in Carnon (Herault) was assigned in a group with S. patens (Mexico-Florida-Delaware group). 

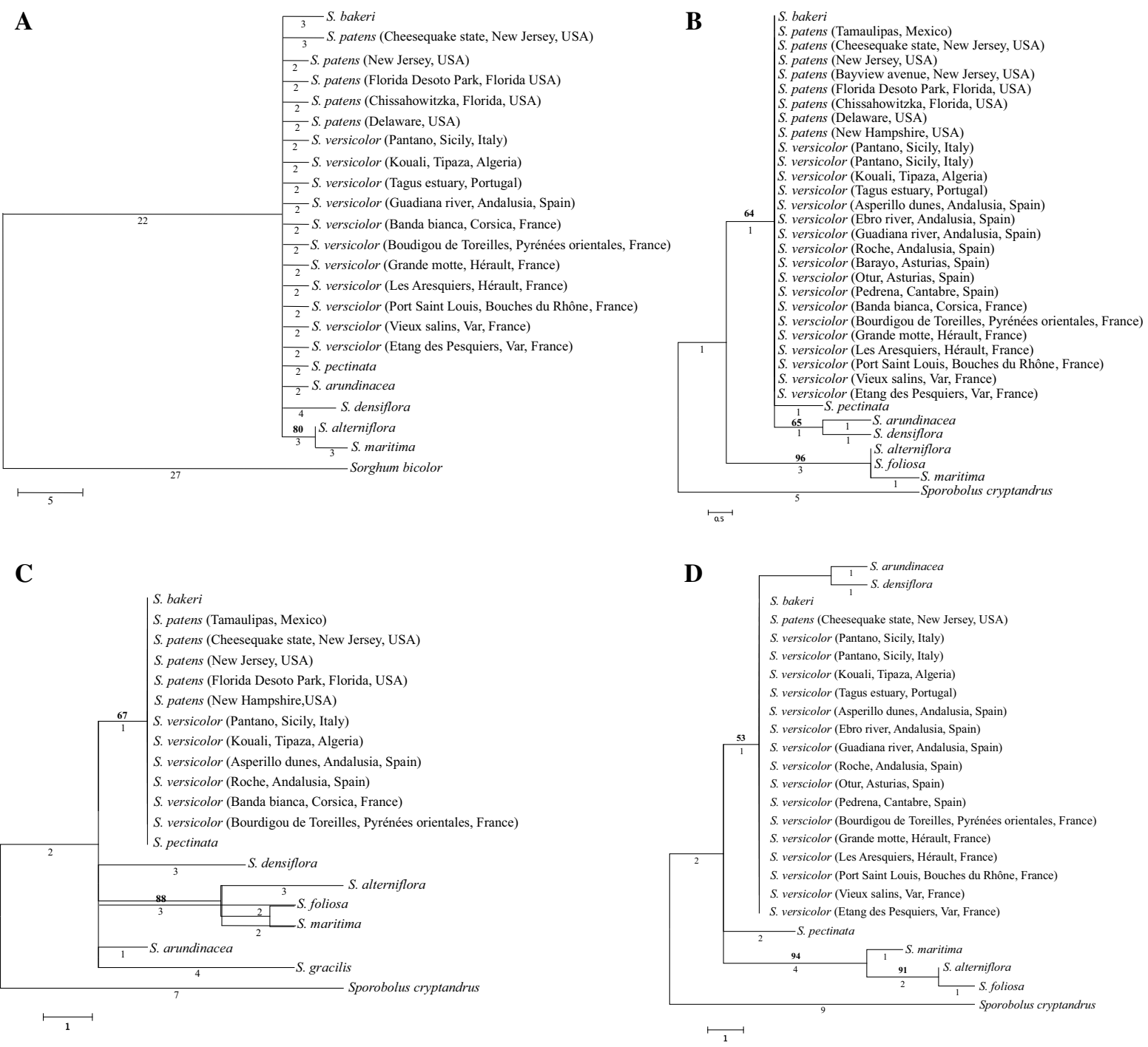

E

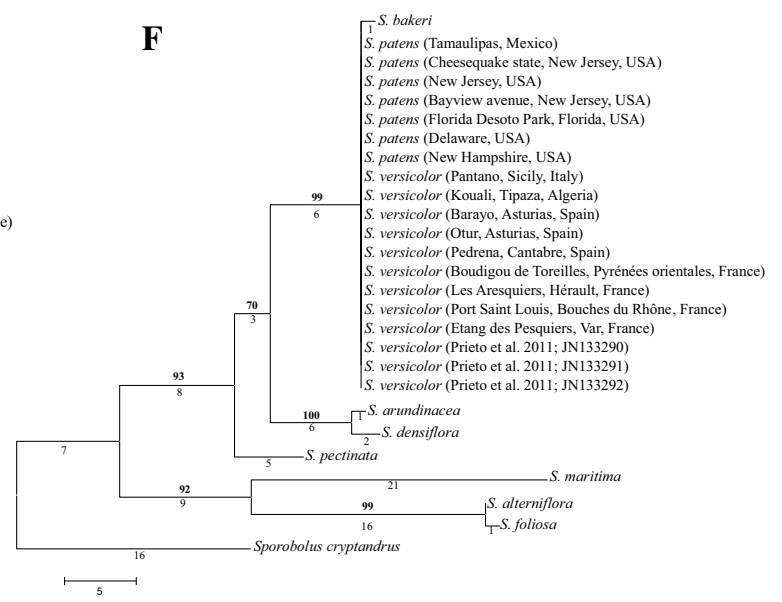




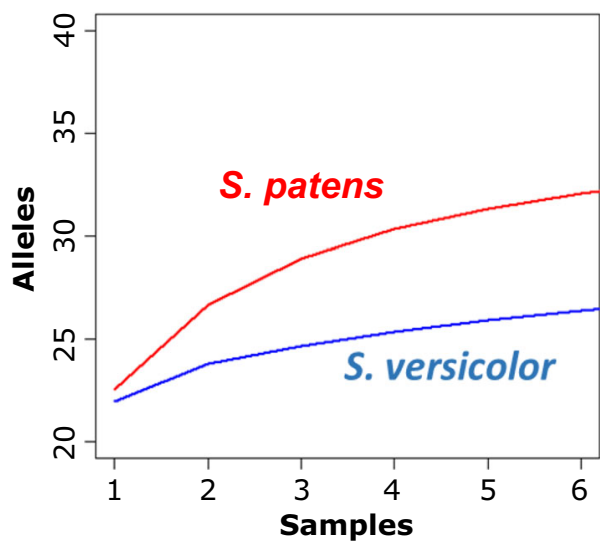

Fig. 3 Rarefaction curves of allelic diversity for the seven SSR loci

The $S$. patens cluster being the most similar to $S$. versicolor (NJ network Fig. 6) is observed all along the Atlantic North American coast from Mexico to Delaware. The cluster 4 which has most of the S.versicolor samples, and the herbarium sample collected by Fabre, are the most similar to $S$. patens according to the NJ network (Fig. 6).

\section{Discussion}

Our results reveal that $S$. versicolor is a tetraploid species with 40 chromosomes, as found in S. patens (Marchant 1968) and no European or North-African populations analyzed can be differentiated genetically from North American S. patens samples as they exhibit similar rDNA ITS and cpDNA sequences. In his monograph of Spartina, Mobberley (1956) stressed the morphological similarities between these two taxa, although several phenotypes were described for $S$. patens (Mobberley 1956). Our results support the hypothesis that all European and African populations of $S$. versicolor are in fact North American S. patens introduced before or at the beginning of the nineteenth-century.

Although some microsatellite variation was detected between $S$. patens and $S$. versicolor, only few genotype differences were observed. Genetic differences regarding microsatellite alleles would most likely result from intraspecific genetic diversity in S. patens-versicolor populations; this is supported by genetic similarities between some North-American $S$. patens and $S$. versicolor samples as can be seen on PcoA results (Fig. 4). The introduction origin could be in the areas covered by the genetic cluster 4 (Fig. 5), i.e. France, North Spain or Italy because the corresponding genotype is the most similar to $S$. patens in the NJ network (Fig. 6). This pattern is also clear in the PcoA analysis (Fig. 4). The S. versicolor samples from Portugal and South Spain, or Algeria are either derived from this introduction or resulted from a second introduction.

Spartina patens is a highly variable rhizomatous species, exhibiting high ecological amplitude along the Atlantic coast of North America from Canada to Central America, colonizing high salt marsh zones, beaches and sand dunes, with variable seed set (Silander and Antonovics 1979). Allozyme studies in native $S$. patens populations (Silander 1984) revealed important polymorphism with a decreased role of vegetative reproduction from dune to marsh habitats. In contrast microsatellite genotyping revealed reduced genetic diversity in $S$. versicolor compared to North American S. patens samples (Fig. 3), which is consistent with a genetic bottleneck following introduction in Europe together with the predominant clonal propagation of the introduced plants. Indeed we found 17 matching SSR genotypes within $S$. versicolor but this number increased to 41 when accounting for one allele error indicating that genetic variation within $S$. versicolor could be mainly of somaclonal variation. Preliminary surveys in $S$. versicolor populations revealed sterile pollen ( $R$. Amirouche, unpublished data), which is in agreement with the observation that this taxon rarely produces seeds (Fabre 1849; San Leon et al. 1999; Tison et al. 2014; our personal observations). Further sampling and phylogeographic analyses are needed in the native region of $S$. patens to better document the history of this taxon and to identify the precise populations that were introduced in the Mediterranean. Although various studies have documented distribution, ecology and plasticity of $S$. patens in North America (e.g. Frasco and Good 1982; Burdick and Mendelssohn 1987; Burdick et al. 1989; Foote and Reynolds 1997; Lonard et al. 2010), very few studies have documented genetic diversity in $S$. patens (e.g. $\mathrm{Wu} \mathrm{2012)}$ and there is a great need to develop DNA-based analyses at the genome level in the native range of this species, which plays an important ecological role, preventing coastal erosion and being used in dune restoration. 


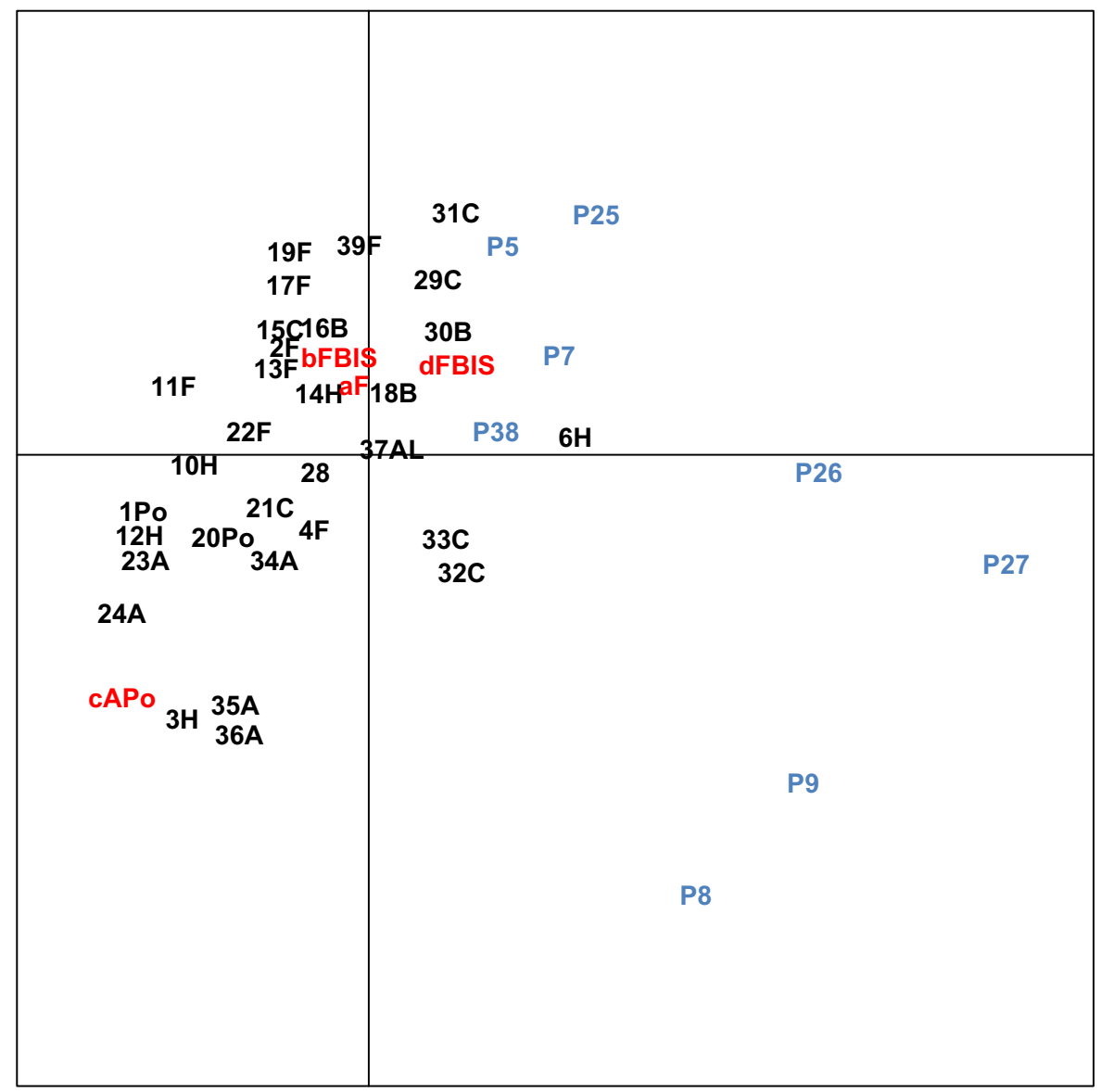

Fig. 4 Principal coordinates analysis (PcoA) of Jaccard distance based on individual SSR genotypes. Upper-case letters indicates the geographical origin of the sample ( $A$ Andalusia, $A L$ Algeria, $B$ Basque area, $C$ Corsica, $F$ France, $H$ Herbarium, $I$ Italy, $P o$ Portugal, $S$ Sicily), except for " $P$ " that corresponds to

Another finding of our molecular phylogenetic analyses is the very close relationship between $S$. patens and $S$. bakeri which exhibit nearly identical (one nucleotide substitution in ITS) nuclear and chloroplast DNA sequences, confirming previous phylogenetic studies (Baumel et al. 2002; Fortune et al. 2007). These two species are hardly separable morphologically, apart from the lack of rhizome in $S$. bakeri, and its preferential freshwater habitat (Mobberley 1956). Thus, the retention of S. bakeri as a separate species might be questioned and would deserve further investigation.

Our study contributes to the worldwide research performed on Spartina invasion (Strong and Ayres
S. patens genotypes. Lower-case letters indicates one of the four clonal genotypes (i.e. identical genotypes among several individuals). The herbarium specimen collected by Fabre corresponds to clone " $b$ "

2013), bearing support for future issues dealing with Mediterranean and Atlantic coastline invasions by Spartina. Indeed if S. versicolor/patens is scattered on the Mediterranean coast and in Southwest Iberian Peninsula (Gulf of Cádiz) where its habitats are small and rare, it is widespread in salt marshes of Gallicean estuaries on the Atlantic Spanish coast (San Leon et al. 1999; "green" genotypes in Figs. 5, 6) probably due to wetter climatic conditions and lower salinities than in the Mediterranean and in the Gulf of Cádiz. In The Gulf of Cádiz, S. versicolor is restricted to a few isolated populations on coastal dunes and brackish marshes where it accumulates high biomass levels but without spreading to large areas, probably due to its 


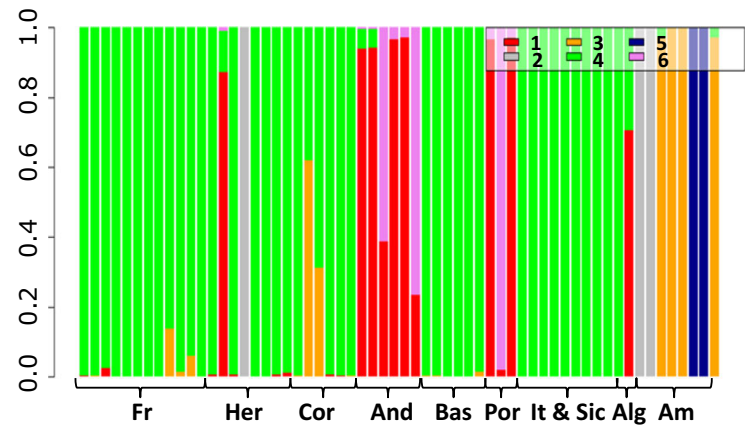

Fig. 5 Assignment of individual SSR genotypes to genetic clusters obtained from a discriminant analysis of principal components $(D A P C)$. The $X$ axis corresponds to the genotypes, which are labeled according to their geographical origin: France (Fr), Herbarium (Herb), Corse (Cor), Andalusia (And), Basque area (Bas), Portugal (Por), Italy (It), Sicily (Sci), Algeria (Alg) and $S$. patens from America $(A m)$. The $Y$ axis indicates the probability of assignment to genetic clusters after DAPC

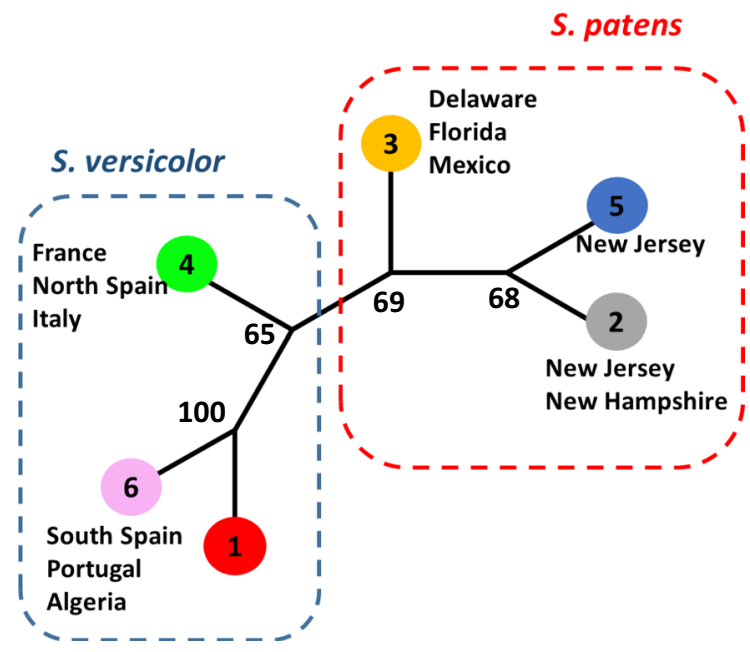

Fig. 6 Neighbor Joining network based on Nei genetic distances computed from allelic frequencies within the genetic groups obtained by the DAPC. Similar colors as for DAPC (Fig. 5) were used. Bootstrap values are indicated below the branches

very low seed set (Castillo, personal observation). Spartina patens has developed physiological mechanisms that make it able to tolerate variable salt and drought stress levels in both salt marsh and dune environments (Casolo et al. 2014). It can therefore invade new habitats if it is dispersed. Concerning recent expansion (since the twentieth century), $S$. patens was observed recently in the British Isles where one patch is known since 2005 on the Sussex coast
(Stace 2010; Hounsome 2013); it was also introduced in China (An et al. 2007) and on the North American Pacific coast (Daehler and Strong 1996a; Ayres et al. 2004), where attempts to control and eradicate it are being conducted. In the Mediterranean region, $S$. versicolor appears to have expanded eastward (e.g. Italy: Valsecchi 1962; Bertacci and Lombardi 2014). In addition to our sampled site in North Africa (Kouali, near Algiers), S. versicolor was recorded on the East Algerian Coast near el Kala and Annaba (Cosson and Maisonneuve 1867). Updated surveys are therefore needed in Europe and North Africa to detect eventually new areas of spread.

Beyond the occurrence and spread of S. versicolor, conservationists and coastal managers must be aware that Spartina species are prone to hybridization, with either native or other introduced species (Strong and Ayres 2013) and further investigations are needed regarding the potential hybridization of $S$. versicolor with native (e.g. S. maritima) and invasive Spartina species (e.g. S. densiflora) in the places where they cooccur. Hybridization is known to play a key role in the Spartina invasion process; specifically in Spain where another recent case of Spartina introduction is documented, involving $S$. densiflora which became an invasive species competing with the native $S$. maritima, with which it also hybridized (Castillo et al. 2008, 2010).

In conclusion, our study provides new insights into the worldwide spread of Spartina and on the introduced origin of $S$. versicolor, which pinpoints new cases of introductions in Mediterranean wetlands, reinforcing the need to clarify the systematics, taxonomy and evolutionary history of introduced plants.

Acknowledgments This work was supported by the "Biological Invasion" Programme of UMR-CNRS Ecobio, University of Rennes 1 (France), the IMBE molecular biology service, the International Associated Laboratory LIA ECOGEN and the Partner University Funds (to M. A.). We gratefully acknowledge financial support from the "Région Bretagne" and the European Union Seventh Framework Programme [FP7CIG-2013-2017; Grant no. 333709 to M. R-G.]. We thank members of herbaria in France (Herbier Montpellier Université, Herbier du Muséum d'Histoire Naturelle de Marseille, Herbier Paris, Université de Rennes 1) for providing access to historical reference samples, and to the many people who helped us getting plant samples from various places (listed in Supplementary table S1), and most particularly: G. Martin, O. Garsmeur, E. Vela, J-M. Lewin, C. Piazza, J. Xiao Wen Wong, (Old World S. versicolor) M-E. Siqueiros, M. Gross and C. Richards (New World S. patens). The authors also thank D. 
Ayres and one anonymous reviewer for helpful comments on an earlier version of this manuscript.

\section{References}

Ainouche ML, Fortune PM, Salmon A, Parisod C, Grandbastien MA, Fukunaga K, Ricou M, Misset MT (2009) Hybridization, polyploidy and invasion: lessons from Spartina (Poaceae). Biol Invasions 11:1159-1173

Ainouche ML, Chelaifa H, Ferreira de Carvalho J, Bellot S, Ainouche AK, Salmon A (2012) Polyploid evolution in Spartina: dealing with highly redundant hybrid genomes. In: Soltis PS, Soltis DE (eds) Polyploidy and genome evolution. Springer, Berlin, pp 225-243

An SQ, Gu BH, Zhou CF et al (2007) Spartina invasion in China: implications for invasive species management and future research. Weed Res 47:183-191

Ayres DR, Smith DL, Zaremba K, Klohr S, Strong DR (2004) Spread of exotic cordgrass and hybrids (Spartina sp) in the tidal marshes of San-Francisco Bay CA, USA. Biol Invasions 6:221-231

Baumel A, Ainouche ML, Levasseur JE (2001) Molecular investigations in populations of Spartina anglica CE Hubbard (Poaceae) invading coastal Brittany (France). Mol Ecol 10:1689-1701

Baumel A, Ainouche ML, Bayer RJ, Ainouche AK, Misset MT (2002) Molecular phylogeny of hybridizing species from the genus Spartina Schreb. (Poaceae). Mol Phylogenet Evol 22:303-314

Baumel A, Ainouche ML, Misset MT, Gourret JP, Bayer RJ (2003) Genetic evidence for hybridization between the native Spartina maritima and the introduced Spartina alterniflora (Poaceae) in South-West France: Spartina neyrautii re-examined. Plant Syst Evol 237:87-97

Bertacci A, Lombardi T (2014) Spartina versicolor Fabre in coastal areas of Tuscany (Italy). Contrib Bot XLIX:49-60

Blum MJ, Bando KJ, Katz M (2007) Geographic structure, genetic diversity and source tracking of Spartina alterniflora. J Biogeogr 34:2055-2069

Bortolus A (2006) The austral cordgrass Spartina densiflora Brong: its taxonomy, biogeography and natural history. J Biogeogr 33:158-168

Bortolus A, Carlton JT, Schwindt E (2015) Reimagining South American coasts: unveiling the hidden invasion history of an iconic ecological engineer. Divers Distrib 21:1267-1283

Boutte J, Aliaga B, Lima O, Ferreira de Carvalho J, Ainouche A, Macas J, Rousseau-Gueutin M, Coriton O, Ainouche M, Salmon A (2015) Haplotype detection from next-generation sequencing in high-ploidy-level species: 45S rDNA gene copies in the hexaploid spartina maritima. G3 6:29-40

Burdick DM, Mendelssohn IA (1987) Waterlogging responses in dune, swale, and marsh populations of Spartina patens under field conditions. Oecologia 74:321-329

Burdick DM, Mendelssohn IA, McKee KL (1989) Live standing crop and metabolism of the salt marsh grass Spartina patens as related to edaphic factors in a brackish, mixed marsh community in Louisiana. Estuaries 12:195-204
Campos JA, Herrera M, Biurrun I, Loidi J (2004) The role of alien plants in the natural coastal vegetation in centralnorthern Spain. Biodivers Conserv 13:2275-2293

Casolo V, Tomasella M, De Col V, Braidot E, Savi T, Nardini A (2014) Water relations of an invasive halophyte (Spartina patens): osmoregulation and ionic effects on xylem hydraulics. Funct Plant Biol 42:264-273

Castillo JM, Mateos-Naranjo E, Nieva FJ, Figueroa E (2008) Plant zonation at salt marshes of the endangered cordgrass Spartina maritima invaded by Spartina densiflora. Hydrobiologia 614:363-371

Castillo JM, Ayres DR, Leira-Docel P, Bailey J, Blum M, Strong DR, Luque T, Figueroa E (2010) The production of hybrids with high ecological amplitude between exotic Spartina densiflora and native $S$ maritima in the Iberian Peninsula. Divers Distrib 16:547-558

Chevalier MA (1923) Note sur les Spartina de la flore française. Bull Soc Bot Fr 70:54-63

Cosson E, Durieu de Maisonneuve (1867) Introduction à la flore d'Algérie. Phanérogamie. Groupe des Glumacées (seu descriptio glumacearum in Algeria nascentium). Exploration Scientifique de l'Algérie, publiée par ordre du Gouvernement. Sciences Naturelles. Botanique. Imprimerie Impériale. Paris

Coste H (1906) Flore de la France. T.III. Librairie des Sciences Naturelles, Paris, p 807

Cottet M, De Montaudouin X, Blanchet H, Lebleu P (2007) Spartina anglica eradication experiment and in situ monitoring assess structuting strength of habitat complexity on marine macrofauna at high tidal level. Estuar Coast Shelf S 71:629-640

Daehler CC, Strong DR (1996a) Status, prediction and prevention of introduced cordgrass Spartina spp. invasions in Pacific estuaries, USA. Biol Conserv 78:51-58

Daehler CC, Strong DR (1996b) Status, prediction and prevention of introduced cordgrass Spartina spp. invasions in Pacific estuaries, USA. Biol Conserv 78:51-58

Daveau J (1897) La flore littorale du Portugal. Bol Soc Brot $14: 4-54$

Dray S, Dufour AB (2007) The ade4 package: implementing the duality diagram for ecologists. J Stat Softw 22:1-20

Drummond AJ, Ashton B, Buxton S et al (2010) Geneious v5.1. http://www.geneious.com

Fabre ME (1849) Description d'une nouvelle espèce de Spartina, abondante sur une portion du littoral méditerranéen. Ann Sci Nat Bot Biol 3:122-125

Felsenstein J (1985) Confidence-limits on phylogenies-an approach using the bootstrap. Evolution 39:783-791

Ferreira de Carvalho J, Chelaifa H, Boutte J et al (2013) Exploring the genome of the salt- marsh Spartina maritima (Poaceae, Chloridoideae) through BAC end sequence analysis. Plant Mol Biol 83:591-606

Foote AL, Reynolds KA (1997) Decomposition of saltmeadow cordgrass (Spartina patens) in Louisiana coastal marshes. Estuaries 20:579-588

Fortune PM, Schierenbeck KA, Ainouche AK, Jacquemin J, Wendel JF et al (2007) Evolutionary dynamics of Waxy and the origin of hexaploid Spartina species (Poaceae). Mol Phylogenet Evol 43:1040-1055

Fortune PM, Schierenbeck K, Ayres D, Bortolus A, Clatrice O, Ainouche ML (2008) The enigmatic invasive Spartina 
densiflora: a history of hybridizations in a polyploidy context. Mol Ecol 17:4304-4316

Frasco BA, Good RE (1982) Decomposition dynamics of Spartina alterniflora and Spartina patens in a New Jersey salt marsh. Am J Bot 69:402-406

Giuliano M, Stanisci A (2010) Biodiversity conservation in coastal areas in molise (Italy). Bol Mus Ist Biol Univ Genova 72:144-147

Gray AJ, Benham PEM, Raybould AF (1990) Spartina anglica - the evolutionary and ecological background. In: Gray AJ, Benham PEM (eds) Spartina anglica-a research review. Institute of Terrestrial Ecology, Natural Environment Research Council, 5-10

Gray AJ, Marshall DF, Raybould AF (1991) A century of evolution in Spartina anglica. Adv Ecol Res 21:1-62

Guénégou MC, Citharel J, Levasseur JE (1988) The hybrid status of Spartina anglica (Poaceae). Enzymatic analysis of the species and the presumed parents. Can J Bot 66:1830-1833

Guindon S, Gascuel O (2003) A simple, fast, and accurate algorithm to estimate large phylogenies by maximum likelihood. Syst Biol 52:696-704

Hacker SD, Heimer D, Hellquist CE, Reeder TG, Reeves B, Riordan TJ Jr, Dethier MN (2001) A marine plant (Spartina anglica) invades widely varying habitats: potential mechanisms of invasion and control. Biol Invasions 3:211-217

Hardion L, Baumel A, Verlaque R, Vila B (2014) Distinct evolutionary histories of lowland biota on Italian and Balkan peninsulas revealed by the phylogeography of Arundo plinii (Poaceae). J Biogeogr 41:2150-2161

Hounsome G (2013) Spartina patens in West Sussex. Bot Soc Br Isles BBSI News 123:66-67

Hubbard JCE (1968) Grasses, 2nd edn. Penguin Books, London

Jaccard P (1901) Distribution de la flore alpine dans le bassin des Dranses et dans quelques régions voisines. Bull Soc Vaud Sci Nat 37:241-272

Jeanmonod D, Burdet HM (1989) Notes et contributions à la flore de Corse IV. Candollea 44:337-401

Jombart T (2008) Adegenet: a R package for the multivariate analysis of genetic markers. Bioinformatics 24:1403-1405

Jombart T, Devillard S, Balloux F (2010) Discriminant analysis of principal components: a new method for the analysis of genetically structured populations. BMC Genet 11:94

Kim S, Rayburn AL, Voigt TB, AinoucheML Ainouche AK, Lee DK (2013) Chloroplast DNA intraspecific phylogeography of Prairie Cordgrass (Spartina pectinata Bosc ex Link). Plant Mol Biol Rep 31:1376-1383

Kowarik I (2003) Human agency in biological invasions: secondary releases foster naturalisation and population expansion of alien plant species. Biol Invasions 5:293-312

Lonard RI, Judd FW, Stalter R (2010) The biological flora of coastal dunes and wetlands: Spartina patens (W. Aiton) G.H. Muhlenberg. J Coast Res 265:935-946

Mansion G, Rosenbaum G, Schoenenberger N, Bacchetta G, Rossell'o J, Conti E (2008) Phylogenetic analysis informed by geological history supports multiple, sequential invasions of the mediterranean basin by the angiosperm family Araceae. Syst Biol 57:269-285

Marchant CJ (1968) Evolution in Spartina (Gramineae). III. Species chromosome numbers and their taxonomic significance. Bot J Linn Soc 60:41-47
Marignani M, Bacchetta G, Bagella S, Carmela Caria M, Delogu F, Farris E, Fenu G, Filigheddu R, Blasi C (2014) Is time on our side? Strengthening the link between field efforts and conservation needs. Biodivers Conserv 23:421-431

Médail F, Verlaque R (1997) Ecological characteristics and rarity of endemic plants from southeast France and Corsica: implications for biodiversity conservation. Biol Conserv $80: 269-281$

Migliore J, Baumel A, Juin M, Fady B, Roig A, Duong N, Médail F (2013) Surviving in mountain climate refugia: new insights from the genetic diversity and structure of the relict shrub Myrtus nivellei (Myrtaceae) in the Sahara Desert. PLoS One 8:e73795

Mobberley D (1956) Taxonomy and distribution of the genus Spartina. Iowa State Coll J Sci 30:471-574

Nei M (1972) Genetic distance between populations. Am Nat 106:283-292

Oksanen J, Blanchet FG, Kindt R et al (2013) vegan: community ecology package. $\mathrm{R}$ package version 2.0-7. http://CRAN. R-project.org/package $=$ vegan

Page HM, Lastra M, Rodil IF et al (2010) Effects of non-native Spartina patens on plant and sediment organic matter carbon incorporation into the local invertebrate community. Biol Invasions 12:3825-3838

Paradis E, Claude J, Strimmer K (2004) APE: analyses of phylogenetics and evolution in $\mathrm{R}$ language. Bioinformatics 20:289-290

Parlatore F (1850) Flora Italiana. I. Tipografia Le Monnier, Firenze

Peakall R, Smouse PE (2006) GenAlEx 6: genetic analysis in excel. Population genetic software for teaching and research. Mol Ecol Notes 6:288-295

Peterson PM, Romaschenko K, Herrera Arrieta Y, Saarela JM (2014) A molecular phylogeny and new subgeneric classification of Sporobolus (Poaceae: Chloridoideae: Sporobolinae). Taxon 63:1212-1243

Posada D (2008) jModelTest: phylogenetic model averaging. Mol Biol Evol 25:1253-1256

Prieto JAF, Cires E, Sanchez Corominas T et al (2011) Systematics and management of natural resources: the case of Spartina species on European shores. Biologia 66:1011-1018

Rousseau-Gueutin M, Bellot S, Martin GE et al (2015) The chloroplast genome of the hexaploid Spartina maritima (Poaceae, Chloridoideae): comparative analyses and molecular dating. Mol Phylogenet Evol 93:5-16

Saarela JM (2012) Taxonomic synopsis of invasive and native Spartina (Poaceae, Chloridoideae) in the Pacific Northwest (British Columbia, Washington and Oregon), including the first report of Spartina $x$ townsendii for British Columbia, Canada. PhytoKeys 10:25-82

Saint-Yves A (1932) Monographia spartinum. Candollea 5:19-100

Sanchéz-Gullón E (2001) Spartina versicolor (Poaceae): novedad agrotológica para Andalucía. Acta Liotan Malacit 26:279-280

SanLeón DG, Izco J, Sánchez JM (1999) Spartina patens as a weed in Galician saltmarshes (NW Iberian Peninsula). Hydrobiologia 415:213-222

Sanz Elorza M, Dana Sánchez ED, Sobrino Vesperinas E (2004) Atlas de las plantas alóctonas invasoras en España. Dirección General para la Biodiversidad, Madrid, p 384 
Silander JA (1984) The genetic basis of the ecological amplitude of Spartina patens. III. Allozyme variation. Bot Gaz 569-577

Silander J, Antonovics J (1979) The genetic basis of the ecological amplitude of Spartina patens. Morphometric and physiological traits. Evolution 33:1114-1127

Stace C (2010) New flora of the British Isles. Cambridge University Press, Cambridge

Strong DR, Ayres DR (2013) Ecological and evolutionary misadventures of Spartina. Ann Rev Ecol Evol Syst 44:389-410

Swofford DL (2001) Phylogenetic analysis using Parsimony (* and other methods). Version 4.0. Sinauer Associates. Sunderland, Massachusetts

Taberlet P, Gielly L, Pautou G, Bouvet J (1991) Universal primers for amplification of three non-coding regions of chloroplast DNA. Plant Mol Biol 17:1105-1109

Tamura K, Peterson D, Peterson N et al (2011) MEGA5: molecular evolutionary genetics analysis using maximum likelihood, evolutionary distance, and maximum parsimony methods. Mol Biol Evol 28:2731-2739

Tison JM, de Foucault B (2014) Flora gallica. Flore de France, Biotope, Mèze
Tison JM, Jauzein P, Michaud H (2014) Flore de la France Mediterranéenne Continentale. Naturalia, Porquerolles

Valsecchi F (1962) Spartina juncea Willd. nuova specie per la Sardegna. Giorn Bot Italy 69:3-47

Valtuena FJ, Preston CD, Kadereit JW (2011) Evolutionary significance of the invasion of introduced populations into the native range of Meconopsis cambrica. Mol Ecol 20:4318-4331

Verlaque R, Aboucaya A, Fridlender A (2002) Les xénophytes envahissants en France: écologie, types biologiques et polyploïdie. Bot Helv 112:121-136

White TJ, Bruns T, Lee S et al (1990) Amplification and direct sequencing of fungal ribosomal RNA genes for phylogenetics. In: Innis MA, Gelfand DH, Sninsky JJ, White TJ (eds) PCR protocols: a guide to methods and applications. Academic Press, New York, pp 315-322

Wu T (2012) Genetic diversity in Spartina patens in remnant patches in the New Jersey Meadowlands. Master thesis. Rutgers University, New Jersey (USA). http://dx.doi.org/ doi:10.7282/T39K498K 